\title{
Evaluation of the single radial haemolysis (SRH) technique for rubella antibody measurement
}

\author{
S. M. RUSSELL ${ }^{1}$, SANDRA R. BENJAMIN ${ }^{1}$, MOYA BRIGGS ${ }^{2}$, MARY JENKINS ${ }^{3}$, \\ P. P. MORTIMER ${ }^{4}$, AND SHEILA B. PAYNE 5
}

From the Wellcome Research Laboratories', Langley Court, Beckenham, Kent, The School of Pathology, The Middlesex Hospital Medical School ${ }^{2}$, Riding House Street, London, The Regional Virus Laboratory, East Birmingham Hospital ${ }^{3}$, Bordesley Green East, Birmingham, The Central Public Health Laboratory ${ }^{4}$, Colindale Avenue, London, and The Public Health Laboratory, St. Luke's Hospital ${ }^{5}$, Guildford, Surrey, UK

SUMMARY Sera from 1258 individuals have been tested by four laboratories for rubella antibody by both the haemagglutination-inhibition and single radial haemolysis techniques. There was good agreement between the results obtained by the two methods. Although sheep red blood cells were used in the single radial haemolysis plates, no problems were encountered with sera from patients with infectious mononucleosis.

The single radial haemolysis technique was found to be simple, convenient, and reliable, and suited to the rapid screening of large numbers of sera to assess susceptibility to rubella in the context of a vaccination campaign. However, since the technique does not detect anti-rubella IgM, it should not be used as the only test to investigate suspected recent infection.

The haemagglutination-inhibition (HAI) test is at present the one most widely used for detecting antibodies to rubella virus. However, this test is laborious and time-consuming to perform: sera must be pretreated to remove non-specific inhibitors; they may require absorption to remove red cell agglutinins; and they must be individually diluted. In addition, the test involves a large number of variables which can give rise to poor reproducibility (Gust et al., 1973).

The single radial haemolysis (SRH) technique was first developed to detect and measure influenza antibody (Russell et al., 1975; Schild et al., 1975) and, because of its simplicity, accuracy, and reproducibility, has now been used for detecting antibodies against rubella virus.

We here report an evaluation of the SRH technique as a replacement for the HAI test in the routine screening of large numbers of sera for rubella antibody.

\section{Material and methods}

RUBELLA SRH TECHNIQUE

Each SRH plate contained a $1 \%$ agarose gel (Indubiose A37, l'Industrie Biologique Français S.A., Gennevilliers, France) with $0 \cdot 1 \%$ sodium

Received for publication 26 October 1977 azide as a preservative. Sheep red cells with rubella HA antigen (Wellcome Reagents Ltd, Beckenham, Kent) chemically bound to their membranes were suspended at a concentration of $2 \%$ in this gel, and $3 \mathrm{~mm}$ diameter wells were cut in it.

Sera were examined undiluted. A $10-\mu l$ volume of test serum was added to each well and allowed to diffuse through the gel overnight at $4^{\circ} \mathrm{C}$. The gels were then flooded with a 1:10 dilution of guinea-pig complement (Wellcome Reagents Ltd) and incubated in a humidified atmosphere at $37^{\circ} \mathrm{C}$ for three hours. Plates were examined immediately or fixed in $10 \%$ formol saline. The diameters of the zones of haemolysis were then measured, and the corresponding annulus areas were calculated (total area minus area of well).

Since some human sera contain sufficient antisheep red blood cell antibody to produce a very small zone of lysis, sera were defined as SRHpositive only if the area of lysis exceeded $5 \mathrm{~mm}^{2}$, that is, the lysis extended more than $0.5 \mathrm{~mm}$ from the edge of the well.

RUBELLA HAI TECHNIQUE

Each participating centre used its routine HAI technique based on the method of Halonen et al. (1967) but individually modified, as detailed in Table 1.

Sera were pretreated with kaolin to remove non- 
Table 1 Variations in HAI technique

\begin{tabular}{|c|c|c|c|}
\hline Centre & $\begin{array}{l}\text { Incubation time of } \\
\text { serum antigen mixture } \\
(H R S)\end{array}$ & $\begin{array}{l}\text { Lowest serum } \\
\text { dilution } \\
\text { tested }\end{array}$ & $\begin{array}{l}\text { Source of } \\
\text { erythrocytes }\end{array}$ \\
\hline $\begin{array}{l}\text { A } \\
\text { B } \\
\text { C } \\
\text { D }\end{array}$ & $\begin{array}{l}3 \\
1 \\
1 \\
\text { Overnight }\end{array}$ & $\begin{array}{l}1 \text { in } 10 \\
1 \text { in } 8 \\
1 \text { in } 8 \\
1 \text { in } 10\end{array}$ & $\begin{array}{l}\text { Day-old chick } \\
\text { Pigeon } \\
\text { Day-old chick } \\
\text { Pigeon }\end{array}$ \\
\hline
\end{tabular}

specific inhibitors. Rubella haemagglutination antigen was supplied by $\mathrm{Dr}$ C. M. P. Bradstreet, Standards Laboratory for Serological Reagents, Central Public Health Laboratory, Colindale, London.

Human sera containing known levels of rheumatoid factor, as measured by the Rose-Waaler technique (Ball, 1950), were supplied by the Regional Immunology Laboratory of East Birmingham Hospital.

DESIGN OF TRIAL

Four laboratories participated in the trial: the Central Public Health Laboratory, Colindale, London, the School of Pathology, Middlesex Hospital Medical School, London, the Regional Virus Laboratory, East Birmingham Hospital, Birmingham, and the Public Health Laboratory, St Luke's Hospital, Guildford, Surrey.

SRH plates were prepared at the Wellcome Research Laboratories and posted at weekly intervals to the participating laboratories with a request that they should be used within 14 days of receipt. Standard positive and negative control sera were provided. Human sera were screened at each centre by both HAI and SRH. Laboratory A examined unselected sera, while the other laboratories included in their series a number of sera known to have low HAI titres or to have given negative results at the lowest dilution tested. Except where specified, sera were tested by SRH after heat inactivation at $56^{\circ} \mathrm{C}$ for 30 minutes but were otherwise untreated and undiluted.

\section{Results}

HEAT INACTIVATION OF SERUM

In the initial stages of the trial all sera were tested by SRH both before and after heating at $56^{\circ} \mathrm{C}$ for 30 minutes in order to destroy complement activity. The SRH results with 146 unheated sera from centre A gave a reasonably good correlation with the HAI results. However, although the calculated correlation coefficient was 0.82 , three sera produced anomalous results: two with confirmed HAI titres of $<1: 10$ each gave SRH zones of
$43 \mathrm{~mm}^{2}$ and $46 \mathrm{~mm}^{2}$ respectively, and one with an HAI titre of 1:80 produced a zone of only $7 \mathrm{~mm}^{2}$. The same 146 sera, when tested after heat inactivation, gave a correlation coefficient of 0.89 , and the anomalies were eliminated. All subsequent results were obtained from heat-inactivated sera.

CORRELATION OF SRH AND HAI

Figure 1 shows HAI and SRH values obtained for 602 heat-inactivated sera tested by centre A. Each point represents a single determination by each technique on a single serum sample. The solid line indicates the calculated regression line for the two test methods, and the dotted lines indicate limits at \pm 1 doubling dilution in the HAI test. The correlation coefficient was calculated to be 0.89. Similar data from centre $B$ are presented

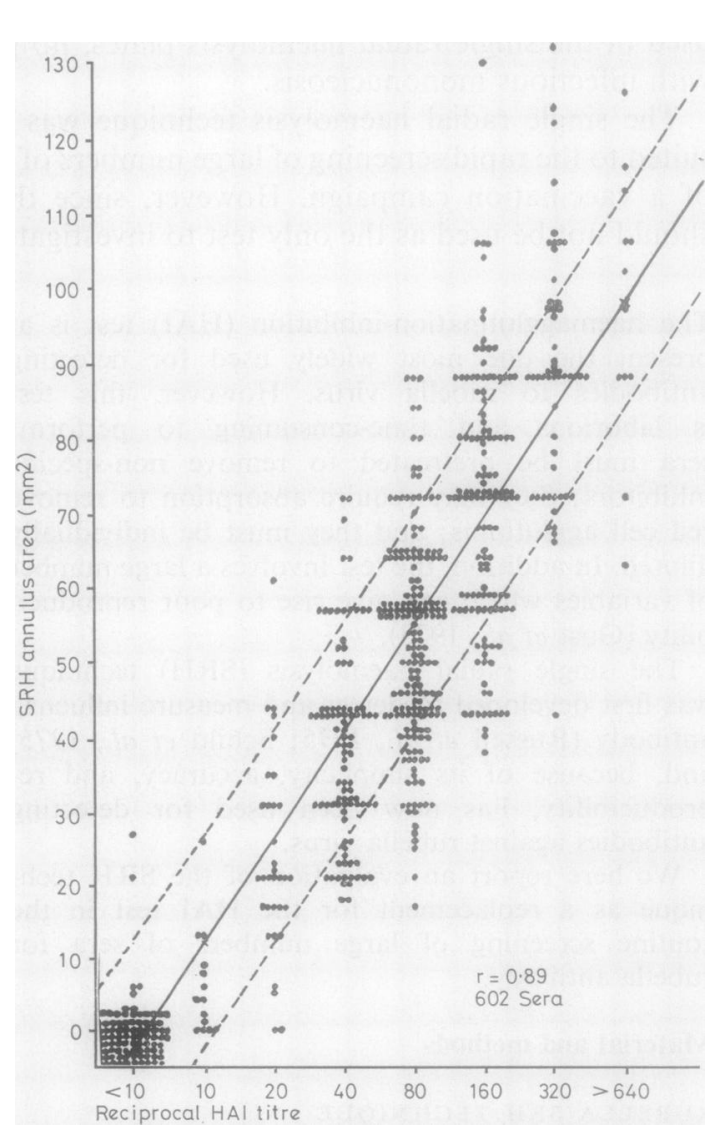

Fig. 1 Correlation between SRH zone area and HAI titre for 602 human sera tested by centre $A$. The solid line indicates the calculated regression line for the two test methods, and the dotted lines indicate limits at \pm doubling dilution in the HAI test. 


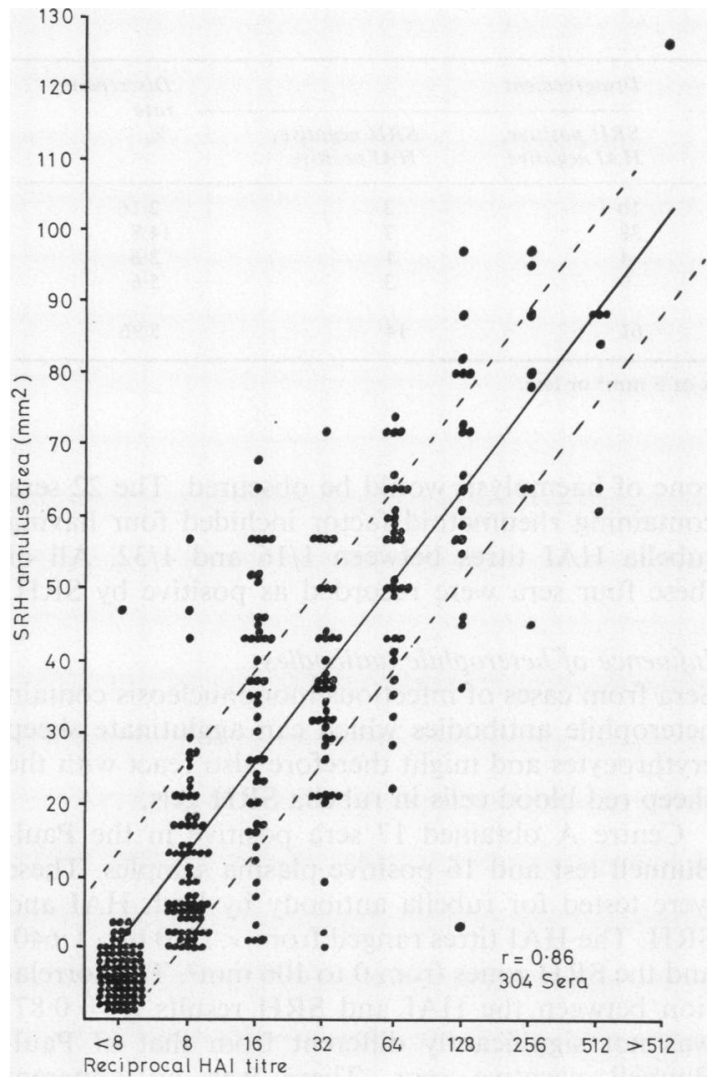

Fig. 2 Correlation between SRH zone area and $\mathrm{HAI}$ titre for 304 human sera tested by centre $B$. The solid line indicates the calculated regression line for the two test methods, and the dotted lines indicate limits at \pm doubling dilution in the HAI test.

in Fig. 2. The correlation coefficient calculated from the 304 sera tested was $\mathbf{0 . 8 6}$.

The scatter of points about the regression line in Figs. 1 and 2 is a measure of the combined errors of both test methods. No firm conclusions can be drawn about the reliability of either test method from these data alone. However, centre A tested 146 sera twice by SRH, and from the results a two-way table has been constructed comparing the first and second estimates (Table 2). In general, the agreement between the two sets of SRH data is satisfactory, but four sera, known to be HIpositive, gave widely discrepant results on replicate testing. These discrepancies could be attributed to the failure to observe some of the fainter radial haemolysis zones when plates were examined microscopically. As these zones were clearly visible when the plates were examined macroscopically, this method of examination was adopted.

A more general analysis of the correlation between the HAI and SRH techniques for the four participating laboratories is given in Table 3, from which it can be seen that an overall discrepancy rate of $5.96 \%$ was achieved. In all, 75 discrepant sera were found out of a total of 1258. Of these, 46 $(61 \%)$ were sera which fell on the borderline between positive and negative in one or other test. The results from centre $B$ contained 37 of these borderline sera, since this laboratory deliberately chose to include a large number of sera known to contain low levels of rubella HAI antibody. The presence of such a high proportion of borderline sera in their sample explains the apparently high discrepancy rate from this centre.

Where possible, the remaining sera were reexamined. Seven were no longer available, and a further six, when retested, gave compatible results by the two techniques, suggesting an operator error in the first test. Sixteen sera consistently gave anomalous results and were subjected to further examination, as detailed below.

\section{Sera containing IgM}

Fourteen sera were found in the course of these trials which, while positive for rubella antibody by

Table 2 Distribution of $S R H$ areas $\left(\mathrm{mm}^{2}\right)$ : centre $A$

\begin{tabular}{|c|c|c|c|c|c|c|c|c|}
\hline \multirow[t]{2}{*}{2 nd result } & \multicolumn{8}{|c|}{ 1st result } \\
\hline & 0.2 .5 & $2 \cdot 6-5$ & $5 \cdot 5-10$ & $10 \cdot 5-20$ & $20 \cdot 5-40$ & $40 \cdot 5-80$ & $>80$ & Total \\
\hline $\begin{array}{c}0-2 \cdot 5 \\
2 \cdot 6-5 \\
5 \cdot 5-10 \\
10 \cdot 5-20\end{array}$ & 32 & 1 & 1 & 1 & $\begin{array}{l}2 \\
1 \\
2\end{array}$ & & & $\begin{array}{r}34 \\
2 \\
2 \\
2\end{array}$ \\
\hline $\begin{array}{l}20 \cdot 5-40 \\
40 \cdot 5-80 \\
>80\end{array}$ & $\begin{array}{l}1 \\
1\end{array}$ & & & 1 & $\begin{array}{r}26 \\
7\end{array}$ & $\begin{array}{l}10 \\
50\end{array}$ & $\begin{array}{l}1 \\
9\end{array}$ & $\begin{array}{r}38 \\
59 \\
9\end{array}$ \\
\hline Total & 34 & 1 & 1 & 2 & 38 & 60 & 10 & 146 \\
\hline
\end{tabular}


Table 3 Summary of $H A I$ and $S R H$ results

\begin{tabular}{|c|c|c|c|c|c|c|}
\hline \multirow[t]{2}{*}{ Centre } & \multirow[t]{2}{*}{ No. of sera tested } & \multicolumn{2}{|c|}{ Agreement: $S R H$ and HAI both } & \multicolumn{2}{|l|}{ Disagreement } & \multirow{2}{*}{$\begin{array}{l}\text { Discrepancy } \\
\text { rate } \\
\%\end{array}$} \\
\hline & & Positive & Negative & $\begin{array}{l}\text { SRH positive, } \\
\text { HAI negative }\end{array}$ & $\begin{array}{l}\text { SRH negative, } \\
\text { HAI positive }\end{array}$ & \\
\hline $\begin{array}{l}\text { A } \\
\text { B } \\
\text { C } \\
\text { D }\end{array}$ & $\begin{array}{l}602 \\
304 \\
139 \\
213\end{array}$ & $\begin{array}{r}497 \\
150 \\
9 \\
127\end{array}$ & $\begin{array}{r}92 \\
109 \\
125 \\
74\end{array}$ & $\begin{array}{r}10 \\
38 \\
4 \\
9\end{array}$ & $\begin{array}{l}3 \\
7 \\
1 \\
3\end{array}$ & $\begin{array}{c}2 \cdot 16 \\
14 \cdot 8 \\
3 \cdot 6 \\
5 \cdot 6\end{array}$ \\
\hline Total & 1258 & 783 & 400 & 61 & 14 & $5 \cdot 96$ \\
\hline
\end{tabular}

Sera defined as negative have HAI titres of $1: 10$ or less or give SRH zones of $5 \mathrm{~mm}^{2}$ or less.

HAI, produced no significant zones of lysis in the SRH test. Fractionation of 10 of these sera on sucrose density gradients and examination of the fractions for the presence of IgM or IgG antibodies by immune-double-diffusion using specific antihuman IgM and IgG sera (Wellcome Reagents Ltd) and for rubella antibody by HAI detected six sera in which anti-rubella antibody was predominantly IgM.

Further tests of the fractions by both HAI and SRH showed that, while anti-rubella antibody in the IgG-rich fractions could be detected by means of either technique, specific antibody in the form of IgM could be detected only by means of the HAI test. These results were confirmed with unfractionated serum samples-four which contained predominantly HAI-positive IgG (titres $1 / 80-1 / 320$ ) gave SRH zones of $51-64 \mathrm{~mm}^{2}$, while four containing a preponderance of HAI-positive IgM (titres $1 / 160-1 / 320$ ) were negative by SRH.

\section{Influence of rheumatoid factor}

Three of the 14 sera which were SRH-negative but had HAI titres of $1 / 16-1 / 32$ were found by centre $B$ to contain rheumatoid factor. These sera did not contain detectable amounts of antirubella IgM.

Since Yanez et al. (1966), Spruance and Smith (1971), and Ogra et al. (1975) have suggested a connection between rheumatoid arthritis and rubella, it was possible that rheumatoid factor might interfere with the rubella SRH test. Therefore a further 22 sera having rheumatoid factor titres ranging from $1: 256$ to $1: 4096$ and also having rubella HAI titres from $>1: 8$ to $1: 256$ were examined by the rubella SRH technique.

A common feature was observed in over half the sera containing both rubella HAI activity and rheumatoid factor. Immediately surrounding the well was an area without haemolysis but with a 'halo' of lysis $2-3 \mathrm{~mm}$ from the edge of the well. The nature of this phenomenon is not known, but it is possible that in sera with low HAI titres the small zone of haemolysis would be obscured. The 22 sera containing rheumatoid factor included four having rubella HAI titres between $1 / 16$ and 1/32. All of these four sera were recorded as positive by SRH.

\section{Influence of heterophile antibodies}

Sera from cases of infectious mononucleosis contain heterophile antibodies which can agglutinate sheep erythrocytes and might therefore also react with the sheep red blood cells in rubella SRH gels.

Centre A obtained 17 sera positive in the PaulBunnell test and 16 positive plasma samples. These were tested for rubella antibody by both HAI and SRH. The HAI titres ranged from $<1: 10$ to $>1: 640$, and the SRH zones from 0 to $106 \mathrm{~mm}^{2}$. The correlation between the HAI and SRH results $(r=0.87)$ was not significantly different from that of PaulBunnell negative sera. There was no apparent difference in the behaviour of serum or plasma samples.

The Paul-Bunnell positive samples were tested also in negative control SRH gels containing sheep erythrocytes but without rubella antigen. Measurable SRH zones were formed by only four out of the 33 samples, the largest zone being only $5.5 \mathrm{~mm}^{2}$ in area.

Thus out of 1258 sera only 10 (including three 을 sera positive for rheumatoid factor), or $0.79 \%$, $>$ were found which consistently gave inexplicably discrepant results by the two techniques used.

\section{Discussion}

In the work presented here, involving the testing in four different laboratories of sera from 1258 individuals, the SRH technique was found to be $\frac{\widetilde{\Phi}}{\Phi}$

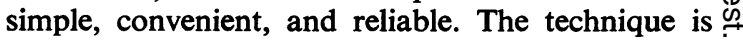
therefore well suited to rapid screening of large 0 numbers of sera. No problems have been encoun- $\bar{D}$ tered with sera from patients with infectious mononucleosis, and the results have shown good agreement with those obtained by HAI.

Skaug et al. (1975), Strannegård et al. (1975), 
and Grillner and Strannegård (1976) have described similar SRH techniques for the estimation of rubella antibodies. They preferred to use chick or pigeon rather than sheep erythrocytes in their tests, but our results show that sheep erythrocytes are perfectly satisfactory when the antigen is irreversibly coupled to the cells by chemical means and not merely by virtue of its haemagglutinin.

The use of sheep erythrocytes does not appear to reduce the specificity of the technique. Although some human sera do contain antibodies which react with sheep erythrocytes, these produce very small zones of total lysis which rarely extend as far as $1 \mathrm{~mm}$ from the edge of the well, and even the Paul-Bunnell positive sera which have been tested caused no problems. Thus in this trial it has not proved necessary to pre-absorb the sera with sheep erythrocytes.

As our results indicate, and as Skaug et al. (1975) and Grillner and Strannegård (1976) have noted, heating sera at $56^{\circ} \mathrm{C}$ for 30 minutes before testing is recommended in order to eliminate the non-specific effects which otherwise occur with a small number of sera.

Our finding that specific IgM antibodies could not be detected by means of the SRH technique confirms the work of Strannegård et al. (1975). Since in other systems IgM is more efficient at complement fixation than is $\mathrm{IgG}$, this result is surprising. However, there are other reports in the literature of the inability of anti-viral IgM to fix complement (Graves et al., 1964; Bellanti et al., 1965; Schmidt et al., 1968; Banatvala, 1969; Scott and Russell, 1972). The reason for this is not yet known but may be either because some viruses may elicit the production of a previously unknown noncomplement fixing IgM or because the spacing of antigens on the viral surface affects the binding of IgM to them.

There is some confusion over the relationship between antibody concentration and zone size found in single radial diffusion systems (Berne, 1972). Skaug and co-workers (1975) and Grillner and Strannegård (1976) have reported a linear relationship between SRH zone diameter and the log of the antibody concentration, whereas our data indicate that it is the area of the zone of haemolysis that relates linearly to the log of antibody concentration (Figs 1 and 2). This divergence probably reflects such factors as the stability of the red cell antigen complex, the time allowed for diffusion, the temperature at which diffusion takes place, and the concentration of agarose used in the different systems. The relationship we have established allows the use of a simple rule of thumb: a doubling of the antibody concentration is equivalent to an increase of $13 \mathrm{~mm}^{2}$ in the area of haemolysis, an approximation which is reasonably accurate over the range of antibody titres likely to be encountered in human sera.

\section{References}

Ball, J. (1950). Serum factor in rheumatoid arthritis agglutinating sensitised sheep red cells. Lancet, ii, 520-524.

Banatvala, J. E. (1969). In discussion, Rubella as a disease. American Journal of Diseases of Children, 118, 66.

Bellanti, J. A., Russ, S. B., Holmes, G. E., and Buescher, E. L. (1965). The nature of antibodies following experimental arbovirus infection in guinea pigs. Journal of Immunology, 94, 1-11.

Berne, B. H. (1972). Discrepant equations derived from the single radial immunodiffusion technique. Immunochemistry, 9, 1256-1259.

Graves, J. H., Cowan, K. M., and Trautman, R. (1964). Characterisation of antibodies produced by guinea pigs inoculated with inactivated foot-and-mouth disease antigen. Journal of Immunology, 92, 501-506.

Grillner, L., and Strannegård, O. (1976). Evaluation of the hemolysis-in-gel test for the screening of rubella immunity and the demonstration of recent infection. Journal of Clinical Microbiology, 3, 86-90.

Gust, I. D., Mathison, A., and Winsor, H. (1973). A survey of rubella haemagglutination-inhibition testing in the Southern States of Australia. Bulletin of the World Health Organisation, 49, 139-142.

Halonen, P. E., Ryan, J. M., and Stewart, J. A. (1967). Rubella hemagglutinin prepared with alkaline extraction of virus grown in suspension culture of BHK-21 cells. Proceedings of the Society for Experimental Biology and Medicine, 125, 162-167.

Ogra, P. L., Chiba, Y., Ogra, S. S., Dzierba, J. L., and Herd, J. K. (1975). Rubella-virus infection in juvenile rheumatoid arthritis. Lancet, i, 1157-1161.

Russell, S. M., McCahon, D., and Beare, A. S. (1975). A single radical haemolysis technique for the measurement of influenza antibody. Journal of General Virology, 27, 1-10.

Schild, G. C., Pereira, M. S., and Chakraverty, P. (1975). Single-radial-haemolysis: a new method for the assay of antibody to influenza haemagglutinin. Bulletin of the World Health Organisation, 52, 43-50.

Schmidt, N. J., Lennette, E. H., and Dennis, J. (1968). Characterisation of antibodies produced in natural and experimental coxsackievirus infections. Journal of Immunology, 100, 99-106.

Scott, R. M., and Russell, P. K. (1972). Complement fixation blocking activity of anti-dengue IgM antibody. Journal of Immunology, 109, 875-877.

Skaug, K., Orstavik, I., and Ulstrup, J. C. (1975). Application of the passive haemolysis test for the determination of rubella virus antibodies. Acta Pathologica et Microbiologica Scandinavia, 83B, 367-372. 
Spruance, S. L., and Smith, C. B. (1971). Joint complications associated with derivatives of HPV-77 rubella virus vaccine. American Journal of Diseases of Children, 122, 105-111.

Strannegard, O., Grillner, L., and Lindberg, I. M. (1975). Hemolysis-in-gel test for the demonstration of antibodies to rubella virus. Journal of Clinical Microbiology, 1, 491-494.

Yanez, J. E., Thompson, G. R., Mikkelsen, W. M., and Bartholomew, L. E. (1966). Rubella arthritis. Annals of Internal Medicine, 64, 772-777.

\section{The May 1978 Issue}

\section{THE MAY 1978 ISSUE CONTAINS THE FOLLOWING PAPERS}

The morphology of cirrhosis P. P. ANTHONY, K. G. ISHAK, N. C. NAYAK, H. E. POULSEN, P. J. SCHEUER, AND L. H. SOBIN

Hepatitis in clinical laboratories 1975-76 N. R. GRIST

Autoclaving practice in microbiology laboratories: report of a survey THE PUBLIC HEALTH LABORATORY SERVICE SUBCOMMITTEE ON LABORATORY AUTOCLAVES

Quantitative recovery of spores from thermophilic spore papers P. H. EVERALL AND C. A. MORRIS

Performance of conveited pressure cookers and two conventional jars for anaerobic bacterial culture R. A. GARGAN AND I. PHILLIPS

Survival of upper respiratory tract bacteria on cotton-wool swabs P. W. ROSS AND H. LOUGH

Use of polyvinylpyrrolidone in the testing of staphylococci for sensitivity to methicillin and cephradine R. BAYSTON

N. gonorrhoeae: pathogenicity of colonial type 5 S. HAFIZ, R. JENNINGS, M. G. MCENTEGART, AND A. E. JEPHCOTT

Effect of clindamycin and lincomycin therapy on faecal flora D. A. LEIGH AND K. SIMMONS

Urine xanthine oxidase activity in urinary tract infection S. GILER, E. F. HENIG, I. URCA, O. SPERLING, AND A. DE VRIES

Urinary excretion of glycosaminoglycans in disseminated neoplasm GERALD MANLEY, LYNNE BOWER, AND ANNA ANSON
Alkaline phosphatase and peroxidase for double immunoenzymatic labelling of cellular constituents D. Y. MASON AND RITA SAMMONS

Cell receptor studies on six anaplastic tumours of the thyroid R. A. A. MACAULAY, A. E. DEWAR, A. O. LANGLANDS, AND A. E. STUART

Grading of astrocytomas using a Quantimet 720 image-analysing computer A. J. ROBERTSON, J. M. ANDERSON, R. A. BROWN, W. SLIDDERS, AND J. SWANSON BECK

Echinococcus granulosus: specific quantification of the two most immunoreactive antigens in hydatid fluids P. MUSIANI, M. PIANTELli, L. LAURIOLA, E. ARRU, AND R. POZZUOLI

Comparison of radial haemolysis with haemagglutination inhibition in estimating rubella antibody P. N. APPLETON AND A. D. MACRAE

IgM-class rheumatoid factor interference in the solid-phase radioimmunoassay of rubella-specific IgM antibodies O. H. MEURMAN AND B. R. ZIOLA

Coagulation and fibrinolytic activity of cerebrospinal fluid MILNE ANDERSON, K. B. MATTHEWS, AND J. STUART

High mean red cell volume: its incidence and significance in routine haematology R. J. L. DAVIDSON AND P. J. HAMILTON

\section{Technical method}

Use of liquid paraffin in the preservation of patho logical specimens M. S. ISRAEL AND L. F. YOUNC

Letters to the Editor

Book reviews

Copies are still available and may be obtained from the PUBLISHING MANAGER, BRITISH MEDICAL ASSOCIATION, TAVISTOCK SQUARE, LONDON, WC1H 9JR, price $£ 3.00$, including postage 